\title{
Automatic content-based analysis of georeferenced image data: Detection of Beggiatoa mats in seafloor video mosaics from the Håkon Mosby Mud Volcano
}

\author{
K. Jerosch ${ }^{\mathrm{a}, *}$, A. Lüdtke ${ }^{\mathrm{b}}$, M. Schlüter ${ }^{\mathrm{a}}$, G.T. Ioannidis ${ }^{\mathrm{b}}$ \\ a Alfred Wegener Institute for Polar and Marine Research, Am Handelshafen 12, D-27570 Bremerhaven, Germany \\ ${ }^{\mathrm{b}}$ Center for Computing Technologies (TZI), University of Bremen, P.O. Box 330 440, D-28334 Bremen, Germany
}

Received 27 January 2006; received in revised form 18 May 2006; accepted 26 June 2006

\begin{abstract}
The combination of new underwater technology as remotely operating vehicles (ROVs), high-resolution video imagery, and software to compute georeferenced mosaics of the seafloor provides new opportunities for marine geological or biological studies and applications in offshore industry. Even during single surveys by ROVs or towed systems large amounts of images are compiled. While these underwater techniques are now well-engineered, there is still a lack of methods for the automatic analysis of the acquired image data. During ROV dives more than 4200 georeferenced video mosaics were compiled for the Håkon Mosby Mud Volcano (HMMV). Mud volcanoes as HMMV are considered as significant source locations for methane characterised by unique chemoautotrophic communities as Beggiatoa mats. For the detection and quantification of the spatial distribution of Beggiatoa mats an automated image analysis technique was developed, which applies watershed transformation and relaxation-based labelling of pre-segmented regions. Comparison of the data derived by visual inspection of 2840 video images with the automated image analysis revealed similarities with a precision better than $90 \%$. We consider this as a step towards a time-efficient and accurate analysis of seafloor images for computation of geochemical budgets and identification of habitats at the seafloor.
\end{abstract}

(C) 2006 Elsevier Ltd. All rights reserved.

Keywords: Image processing; Automatic image analysis; Video mosaics; Beggiatoa detection; Watershed transformation; Relaxation labelling

\section{Introduction}

The dynamic development of high-technology underwater vehicles as remotely operated vehicles (ROVs), autonomous underwater vehicles (AUVs), or submersibles-designed for marine scientific

\footnotetext{
*Corresponding author. Tel.: + 4948311261 ; fax: +4948311425 .

E-mail address: kjerosch@awi-bremerhaven.de (K. Jerosch).
}

applications and offshore industry - has led to a significant increase of geodata derived by chemical, optical, and acoustic sensors. These underwater vehicles can be navigated and positioned very accurately and are often equipped with highresolution digital cameras and video systems. This allows generation of georeferenced images and video mosaics by combination of the video stream and navigation data. Such image data are mostly analysed manually at present, which is a very 
labour-intensive and time-consuming task. The increasing application of ROVs and AUVs for scientific objectives or for maintenance of pipelines and platforms by offshore industry requires timeand cost-efficient techniques for analysis of georeferenced underwater images. As a step in this direction, a software platform and specified modules for the automatic content-based analysis and attribution of georeferenced image data from the underwater domain - the IBU software - was developed.

In this study we introduce the IBU software as a generic module-based system and its application for the automatic detection of bacterial mats living at the seafloor of organic-rich coastal sediments or at offshore mud volcanoes. For this purpose we used video mosaics from the Håkon Mosby Mud Volcano (HMMV) acquired during six dives of the ROV Victor6000 (IFREMER) with the video mosaicing software Mosaicing Advanced Technologies Integrated in a Single Software Environment (MATISSE) (Allais et al., 2004; Vincent et al., 2003) during a cruise by $R V$ Polarstern (Klages et al., 2004).

\subsection{Scientific background}

Marine mud volcanoes have been observed worldwide (e.g. Kopf, 2002; Milkov, 2000; Sager et al., 2003, 2004). They are, like the HMMV, often located at tectonically active areas of continental margins (Fig. 1). Upward flow of mud from deeper geological strata, enhanced temperatures, high inventories and fluxes of methane and other hydrocarbons, and occurrence of specific chemoautotrophic communities are characteristics for marine mud volcanoes (Hjelstuen et al., 1999; Kopf, 2002; Milkov, 2000). The methane may accumulate in the sediments and forms gas reservoirs such as gas hydrates (solid methane). At mud volcanoes, pore water, gas, and mud are expelled from deep beneath the seafloor forming mounds and craters at the seafloor (Fig. 2d,f). Active mud volcanoes are therefore a seep for natural gas (methane) and are often densely populated by bacteria, tube worms, bivalves, and other symbiotic organisms (Gebruk et al., 2003; Milkov et al., 2004; Pimenov et al., 2000; Sahling et al., 2005; Sauter et al., 2006; Smirnov, 2000; Soltwedel et al., 2005).

The methane emanating from the seafloor is often very efficiently used by a symbiosis of archaeal and bacterial microorganisms, forming chemoautotrophic communities, that are able to oxidise methane with sulphate which is abundant in seawater. The main microbial processes are anaerobic methane oxidation (AOM) (Boetius et al., 2000) coupled to sulphate reduction and aerobic or anaerobic oxidation of sulphide.

Colonists are chemoautotrophic bacteria using the enzymatic oxidation of reduced compounds as a basic anabolic energy source or metazoan organisms that live in symbiosis with these bacteria, such as pogonophorans (with bacterial symbionts) and bivalves (Sahling et al., 2003). Microbially mediated anaerobic oxidation of methane (AOM) is the major biological sink of methane in marine sediments. Hence, this process is crucial in maintaining a sensitive balance of our atmosphere's greenhouse gas content (Hinrichs and Boetius, 2002).

At the HMMV, three main habitats have been described in previous studies (Gebruk et al., 2003; Jerosch et al., accepted; Milkov et al., 1999): 1. a central, barren area of sediment not colonised by sulphur-oxidising communities; 2 . the zone of highest methane turnover which is indicated by the presence of white mats of giant sulphur-oxidising bacteria (Beggiatoa) on the seafloor (Fig. 2). These bacterial mats cover large areas around the centre of the HMMV; 3. pogonophoran tubeworm fields populating the hummocky part of the HMMV outside of the centre.

Chemoautotrophic communities, i.e. organisms which are fuelled by dissolved chemical constituents, can indicate the presence of active gas seeps. Hence, at HMMV, Beggiatoa and pogonophorans can be used as indicators for enhanced methane consumption. The investigation of their distribution and their density distinguishes between areas with high versus low methane discharge. This is important because there are still gaps in our understanding about the degree of methane oxidation in mud volcano sediments.

\subsection{Investigation area $H M M V$}

HMMV is an active mud, fluid, and methaneventing seep, located at $1250-1266 \mathrm{~m}$ water depth in the centre of the most recent Bear Island fan slide valley at $72^{\circ} 00.25^{\prime} \mathrm{N} 14^{\circ} 43.50^{\prime} \mathrm{E}$ (Fig. 1). HMMV is considered as the only active mud volcano in an arctic area and since its discovery in the 1989-1990 SeaMARC II imagery (Crane et al., 1995) has been studied by multidisciplinary research (Egorov et al., 1999; Gebruk et al., 2003; Ginsburg et al., 1999; 


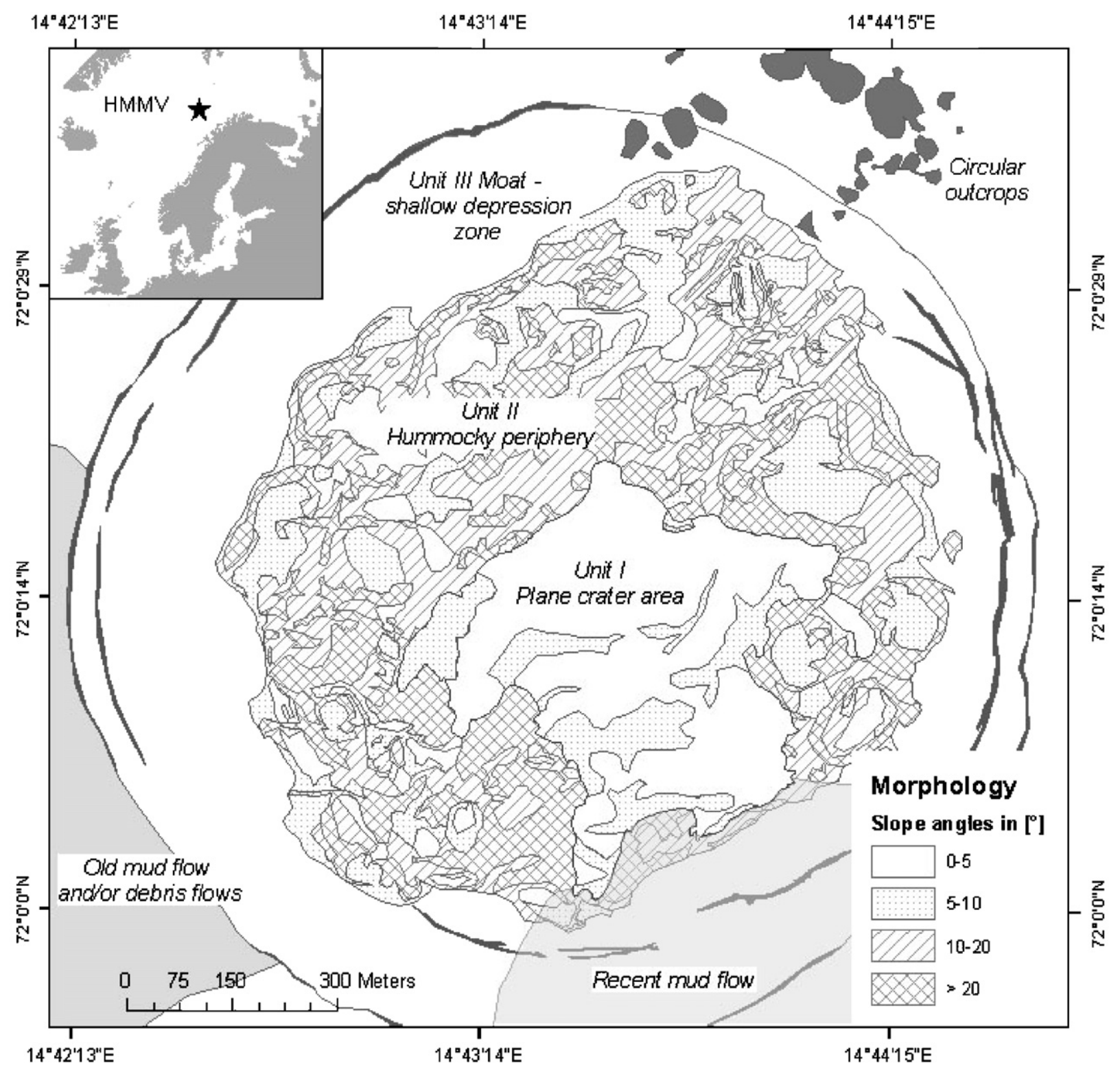

Fig. 1. Regional setting of the HMMV and its morphological structure. The mud volcano is arranged into three morphologic units, which refer to differences in slope angles. These angles were derived from the microbathymetric investigation of the mud volcano (Edy et al., 2004; Jerosch et al., 2005).

Lein et al., 1999; Milkov et al., 1999, 2004; Smirnov, 2000; Soltwedel et al., 2005; Pimenov et al., 2000).

HMMV displays a caldera with a circular shape $(\sim 1 \mathrm{~km}$ in diameter) which can be divided into three concentrically arranged morphological units (Fig. 1): 1. the flat central zone of $400-500 \mathrm{~m}$ diameter with highly reduced, methane-containing non-stratified sediments (Lein et al., 1999). In the thermal "eye" of the volcano, temperatures as high as $22^{\circ} \mathrm{C}$ at $2 \mathrm{~m}$ depth and very steep gradients up to
$3{ }^{\circ} \mathrm{C} / \mathrm{m}$ were observed (Kaul and Heesemann, 2004). This zone contains areas mostly uncolonised by epi/megafauna but in the southern and southwestern part also the regions with the highest density of bacteria coverage. 2. The hummocky periphery with slope angles greater than $20^{\circ}$ and a relief of $8-10 \mathrm{~m}$ in height enclosing the centre. This second unit is minimum 10 to maximum $440 \mathrm{~m}$ wide and is mostly colonised densely by pogonophorans and sparsely by Beggiatoa. 3. A shallow depression 

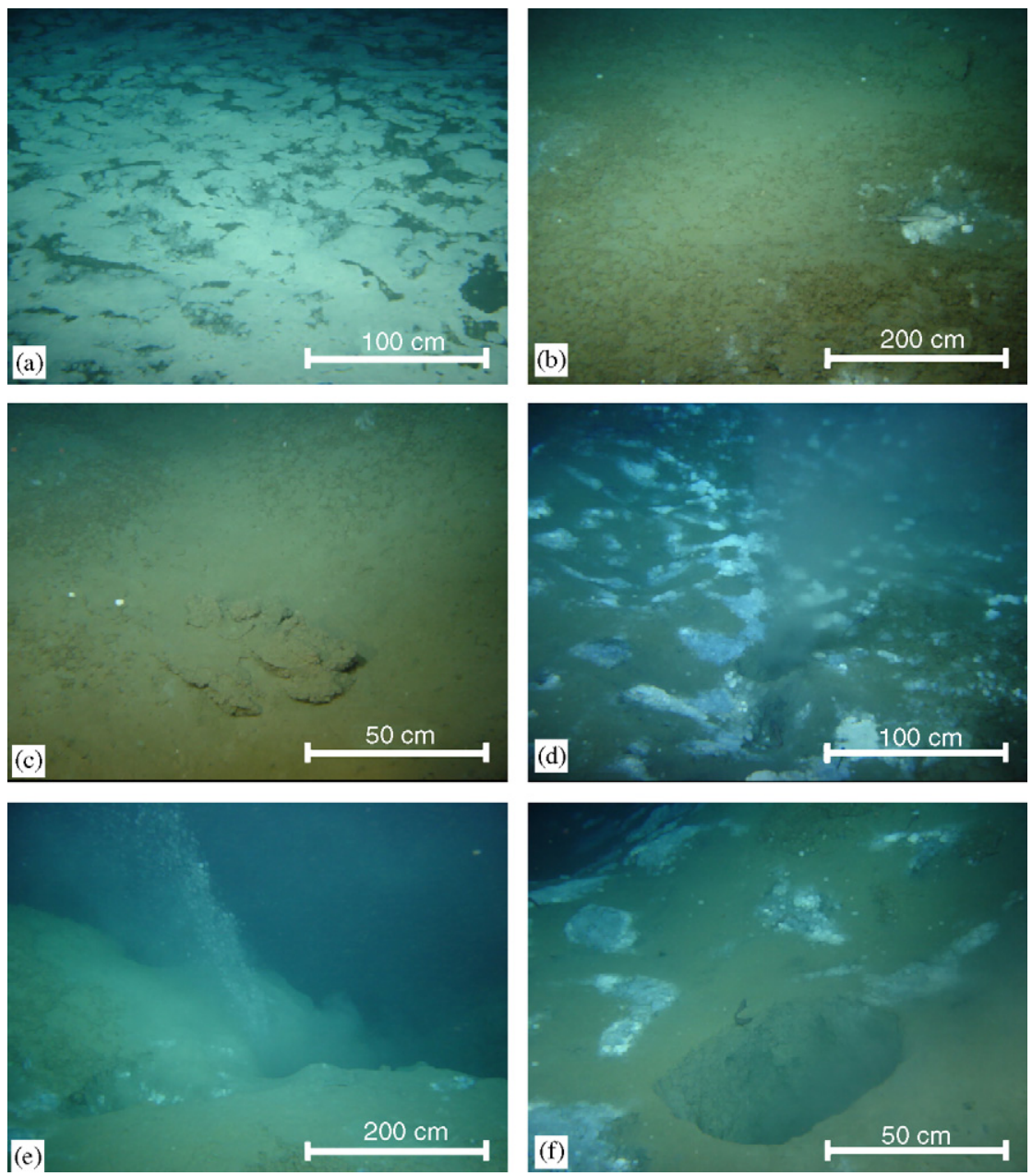

Fig. 2. Observations of chemoautotrophic communities indicating AOM in the sediment layer, and other features revealing gas and fluid discharge at the HMMV. The oblique photographs have been recorded during dives of Victor6000. (a) Greater than $50 \%$ coverage of Beggiatoa occurring in the southern and southeast part of the crater. (b) 20-50\% coverage of Beggiatoa in an area of fluid discharge. (c) 0-20\% Beggiatoa coverage and more than 50\% pogonophorans, a combination covering a majority of the relief-rich periphery. (d) Free gas escape. (e) Authigenic carbonate precipitations as a result of AOM. (f) Fluids coming through a $30 \mathrm{~cm}$ diameter hole in the mud, colonised by Beggiatoa and fish.

surrounding the mud volcano, the moat area, comprises the third unit; which is characterised by very small slope angles (mean value $1.58^{\circ}$ and apparently no colonisation - neither by pogonophorans nor Beggiatoa (Jerosch et al., accepted)).

Major motile epi/megafauna components at HMMV are brittle stars, pantopods (Pycnogonida) and benthic fish (mainly Zoarcidae, Liparidae, and Rajidae; Milkov et al., 1999). The highest densities of fish were observed in the central part of the crater (Gebruk et al., 2003). Large molluscs, common representatives of many mud volcanoes and gas seeps, are completely missing at HMMV (Soltwedel et al., 2005).

\subsection{Data acquisition and processing}

Multidisciplinary investigations of methane fluxes and related processes at the HMMV were conducted during the cruise ARK XIX3b of $R V$ Polarstern in summer 2003. By means of the ROV Victor6000 (operated by IFREMER) the topography of HMMV was mapped and video observations of the seafloor were recorded. Further details of the ROV specification concerning water column and sediment sampling, not directly related to this study, are reported in Klages et al. (2004). On six dives of the ROV Victor6000 video mosaicing was performed during more than $50 \mathrm{~h}$ dive time. 
The ROV navigated at an altitude of $3 \mathrm{~m}$ above the seafloor with a constant speed of about $0.3 \mathrm{~m} \mathrm{~s}^{-1}$. This ensured a high image quality for the vertical camera installed at the bottom of the ROV's tool sled. Since the aperture of the camera is $60^{\circ}$, the width of the generated video mosaics is about the same as the altitude of survey. The entire length of the video profiles is about $35 \mathrm{~km}$ (more than 4200 video mosaics).

The video stream generated by the vertical camera along the ROV transect was processed in real-time using the MATISSE software (developed by IFREMER). This mosaicing software, based upon image and signal processing components (Allais et al., 2004; Vincent et al., 2003), produces georeferenced mosaics by combining the video input and high-precision underwater navigation, as ultra short base line (USBL). The video mosaics were recorded and integrated into the Geographical Information System (GIS) ArcGIS 9.0 (ESRI). In total 2840 georeferenced mosaics have been analysed by visual inspection. For each mosaic spatial entities as occurrence of Beggiatoa mats, pogonophorans, or uncovered mud were digitised as polygons within the GIS, described by specific attributes, and stored within a geodatabase. This allowed a detailed spatial analysis focusing on the distribution of different biogeochemical habitats at HMMV (Jerosch et al., accepted). The manually obtained geoinformation served as validation data during development and for the application of the IBU software.

\section{The IBU software}

The IBU software is a generic framework for the automatic analysis of georeferenced image data. It is generic in the sense that it provides an interface to link and import additional analysis modules. Therefore, it is adaptable to different scientific objectives concerning the analysis of georeferenced image data. It offers functionality to access different image formats, to read metadata associated with images (e.g. world file used for georeferencing), for coordinate transformation or basic rendering of maps using the OpenMap (tm) toolkit (http:// www.openmap.org), and provides specific image processing functionality. Besides automated image analysis, a component for manual image annotation by keywords and a classification scheme defined and selected by the user are implemented. In the studies presented herein, the software is applied to and compared with the spatial analysis of the distribution of bacterial mats at HMMV derived by visual inspection of georeferenced video mosaics.

\section{Image analysis}

During dives by ROVs, submersibles, and AUVs large data volumes of video mosaics and other geotiffs are recorded (just one campaign of six dives by Victor6000 generated more than 4200 mosaics and geotiffs, Fig. 3). Due to this increasing deployment of image recording devices geodatabase systems and spatial analysis by GIS become a demand. To cope with this high data volumes the concepts presented herein consist of a data reduction and data analysis component. Data reduction includes the automatic identification of data and non-data regions within the video mosaics. By this means the data region is enclosed by a polygon and separated from the background (Fig. 4).

This polygon can be exported to the GIS for further processing. The identification and quantification of bacterial mats and other features is part of the data analysis by image processing.

\subsection{Extraction of mosaic data regions}

Basically georeferenced and other images are composed of a rectangular array of pixels. During video surveys a strip of this rectangular array is covered by data whereas a background colour is assigned to the non-data region. Non-data regions are marked by black pixels $(R G B=\{0,0,0\})$ by the MATISSE software (Fig. 4).

In the first step of our automated image analysis these non-data regions are extracted from the video mosaic. For this purpose, the input image is binarised by taking the maximum value of the three $(R, G, B)$ channels and applying a threshold of 0 . Then the regions in the binary image are extracted using a Grassfire-like transform (Ballard and Brown, 1982) and represented by their boundaries transformed to geographic coordinates (in terms of geotiffs so-called world coordinates). Fig. 4 displays a mosaic produced by the MATISSE system and the extracted data regions (marked yellow in Fig. 4). The data containing polygon can be converted into a shape file and integrated into the GIS. By this means the area-on a $\mathrm{m}^{2}$-basis - covered by image information can be derived and attributes describing the content (e.g. occurrence of Beggiatoa) can be assigned. 


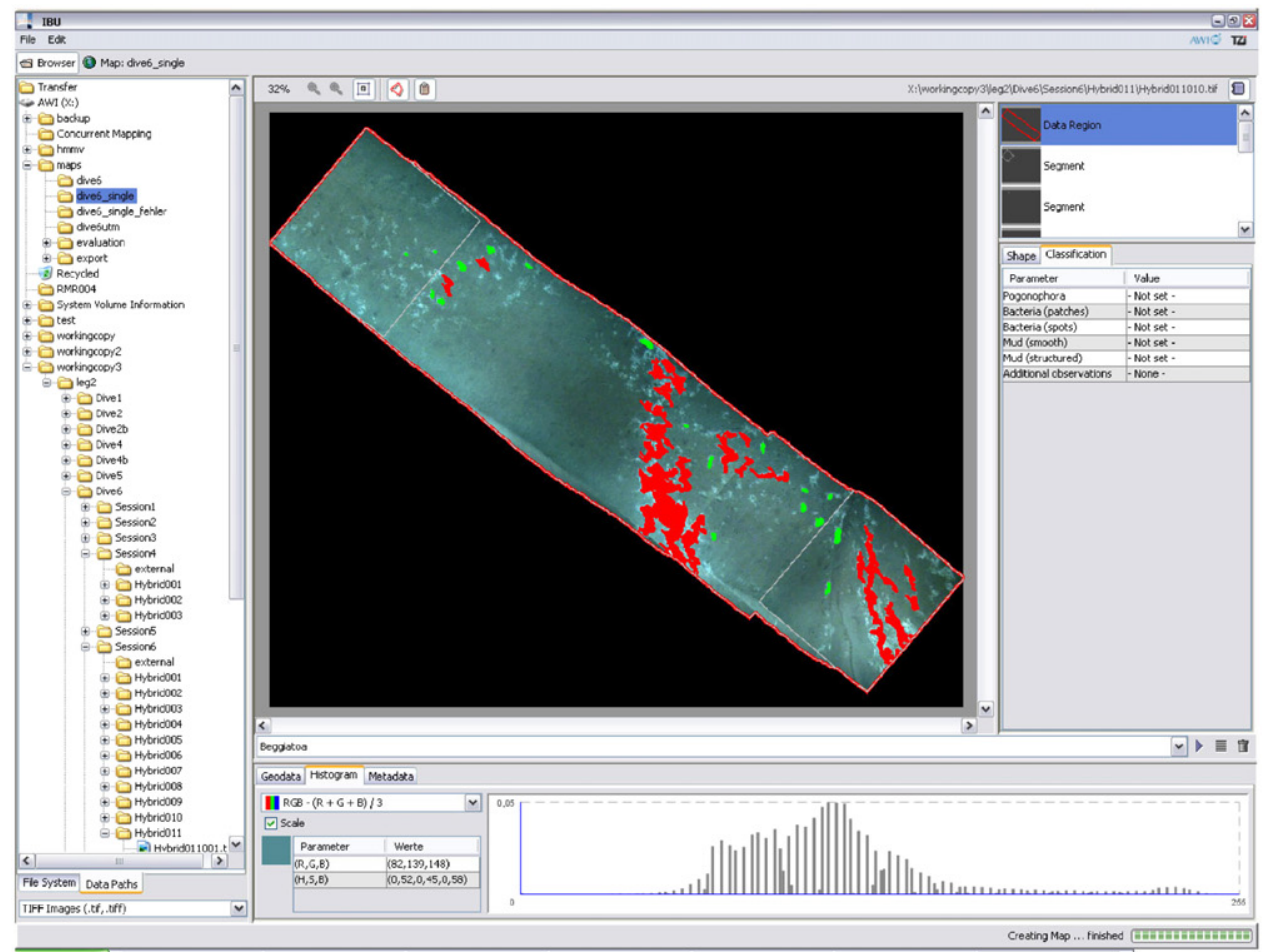

(a)

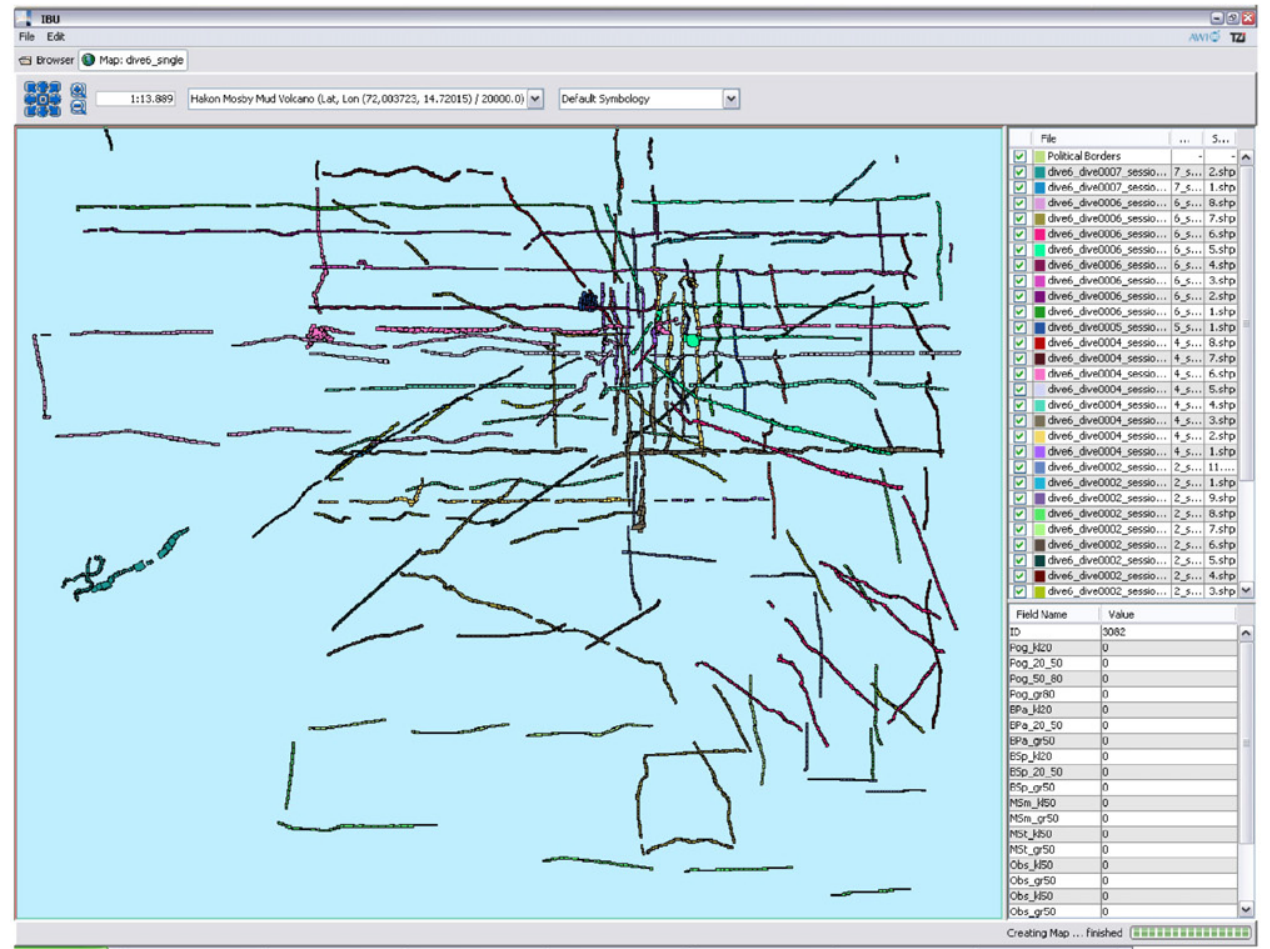

(b)

Fig. 3. (a) Analysis view and (b) map view of the IBU application. The map view shows amount and distribution of the georeferenced video mosaics derived during the ROV dives. 


\subsection{Extraction and handling of data region overlaps}

Associated to surveys by underwater vehicles and the mosaicing process, successive mosaics might partially overlap by a small extent (Fig. 5). Therefore, two neighbouring mosaics contain similar data for the small overlapping area. This might cause a slight overestimation of the entire area. This redundant information is eliminated by an automated analysis step. Within a single treatment (a row of consecutive images, Fig. 5), the positioning is accurate enough to identify such overlapping segments. We further divide the area covered by the

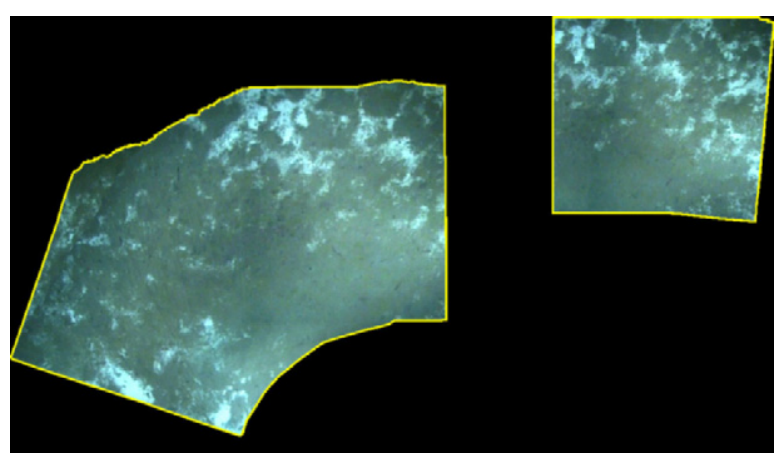

Fig. 4. Identification of the data containing region within a video mosaic and enclosure of this area by a polygon (yellow line). mosaics of a treatment into segments associated with a distinct set of images that we call atomic segments. These atomic segments are the basis for the quantification of bacterial coverage in the export of results described in Section 3.4.

Let $W$ be the set of the extracted data regions for a single treatment. Then $W$ is divided into a set of atomic segments $A$ using the following algorithm:

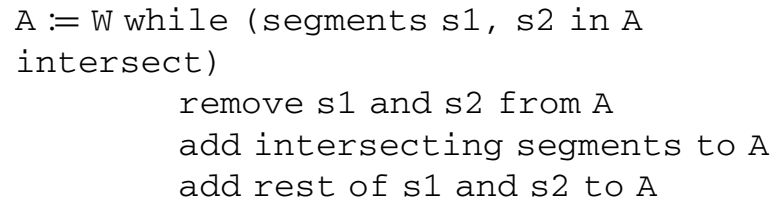

\subsection{Segmentation of bacterial mats}

The segmentation process for identification of bacterial mats (Beggiatoa mats) is mainly divided into two steps:

(1) an initial region-based oversegmentation gained by a watershed transform (Beucher, 1991; Roerdink and Meijster, 2000),

(2) a relaxation-based labelling (Kittler and Illingworth, 1986) of the resulting image regions into bacterial and non-bacterial regions.

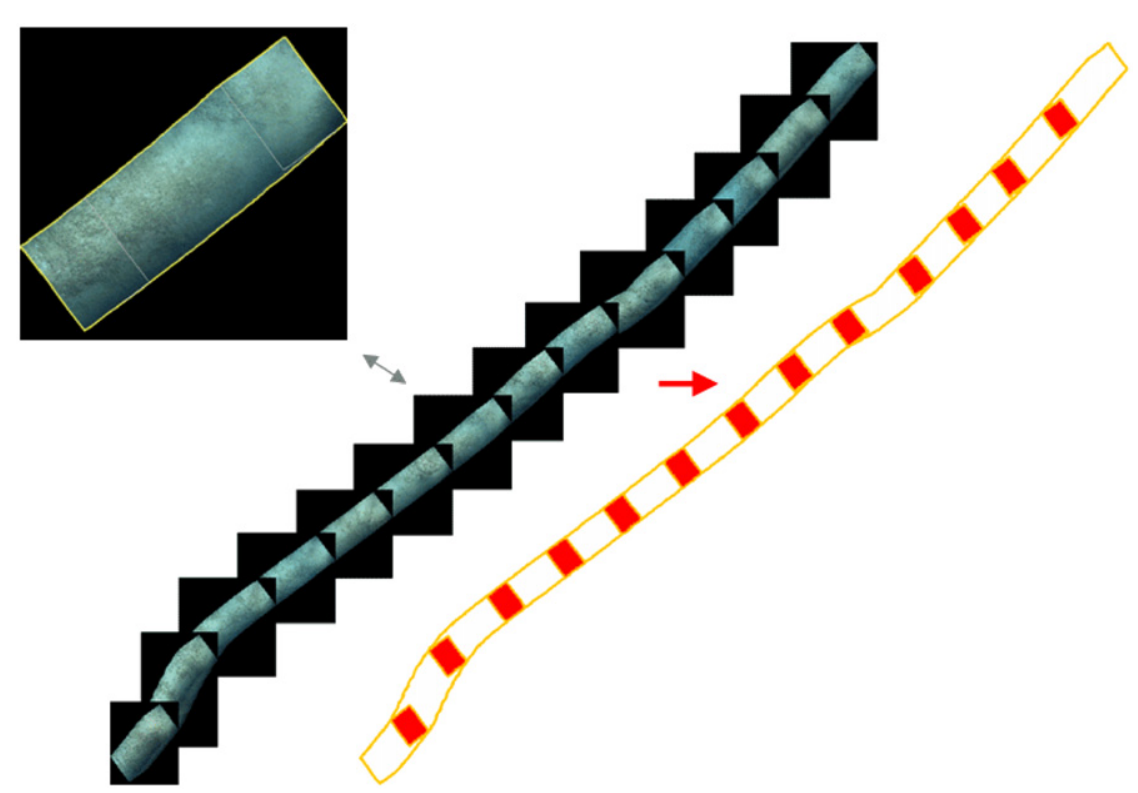

Fig. 5. Overlapping data regions in consecutive video mosaics (overlaps marked red). 


\subsubsection{Region-based pre-segmentation by watershed transformation}

In the first analysis step the input image is converted to greyscale, smoothed by a $3 \times 3$ median (Ballard and Brown, 1982) operator and presegmented by the application of a watershed transformation (Roerdink and Meijster, 2000; Beucher, 1991). The main idea is to partition the image into a set of disjoint homogenous regions $R=$ $r_{0}, \ldots, r_{n}$ based on grey value discontinuities. Therefore the gradient image - e.g. the first derivative of the input image - is interpreted as a topographic surface (see Fig. 6) and iteratively flooded from local minima. The result is a region-based oversegmentation of the input image. Fig. 7 shows an example image with Beggiatoa mats and the resulting regions of the initial segmentation step.
The set of resulting image regions is the basis for the following classification into bacterial and nonbacterial regions.

\subsubsection{Relaxation-based labelling of pre-segmented regions}

In the labelling step we utilise the spatial correlation of the bacterial image regions. We apply a probabilistic approach - relaxation labelling (Kittler and Illingworth, 1986) - to assign labels in $L=$ $\left\{l_{0}, l_{1}\right\}$ (where $l_{0}$ : bacterial region, $l_{1}$ : non-bacterial region) with probabilities $P_{i}\left(l_{k}\right)$ to regions $r_{i}$ gained by the initial segmentation. We start with a rough initial classification into bacterial and non-bacterial regions and confine the classification in an iterative manner during the relaxation process.

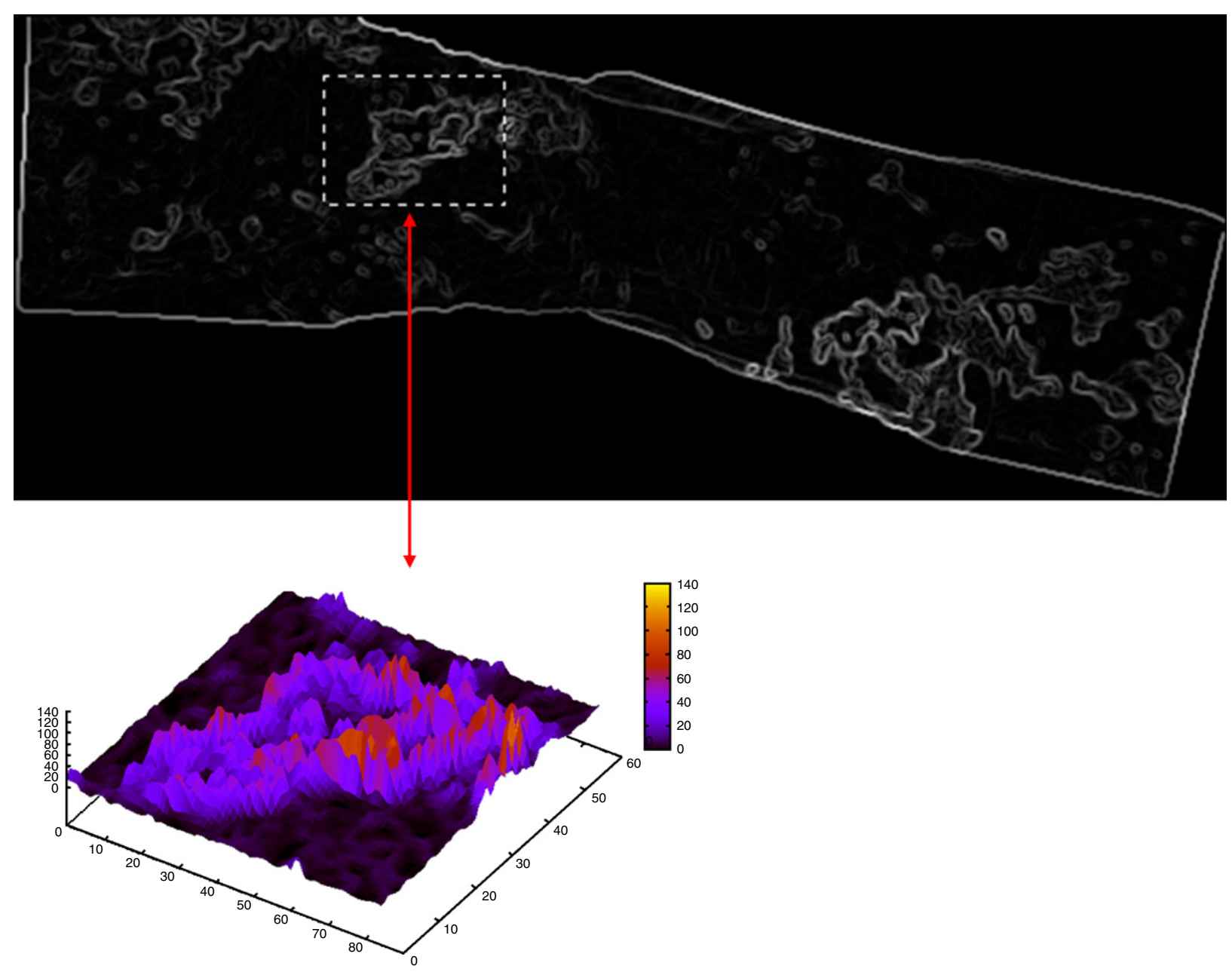

Fig. 6. Gradient image gained by the application of a Sobel (Davies, 1990) edge detector and interpretation as a topographic surface. 

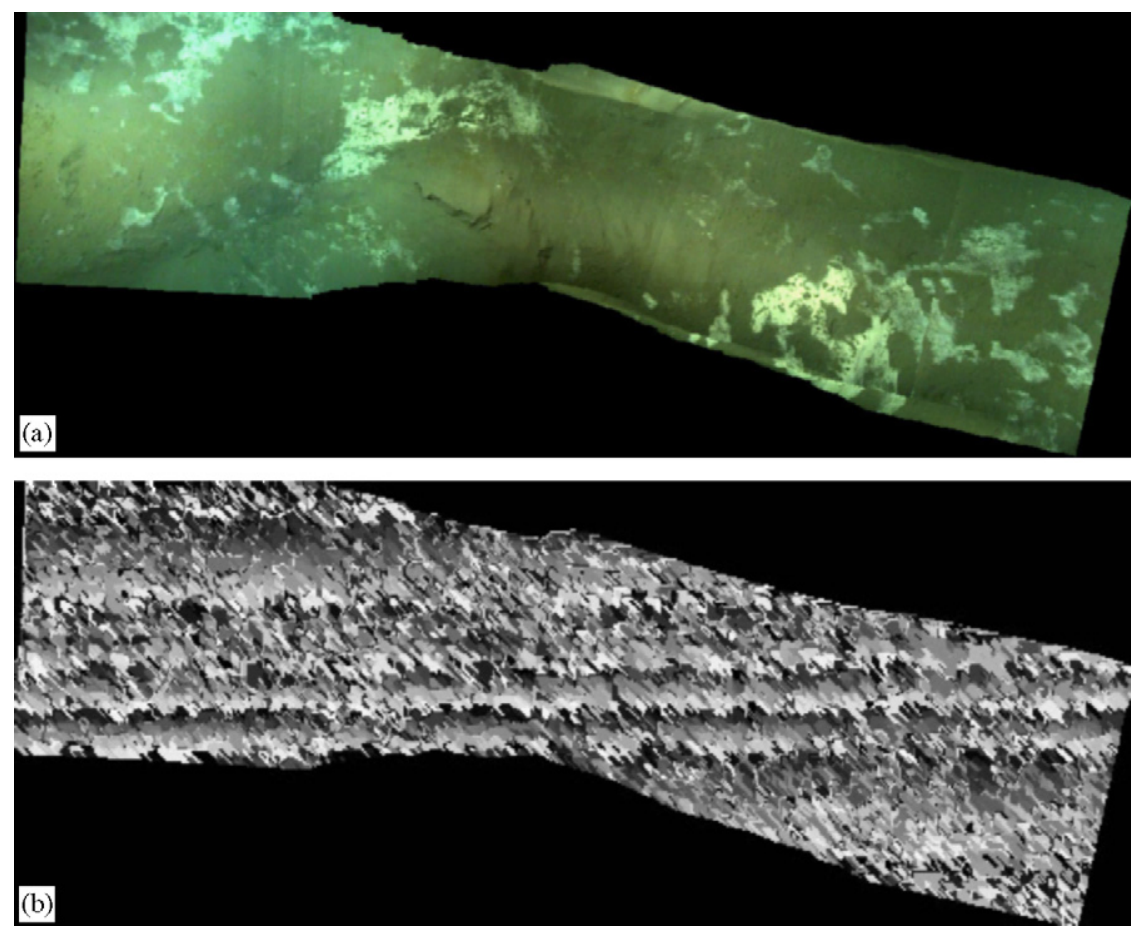

Fig. 7. (a) Sample image with Beggiatoa mats (light areas). (b) Initial watershed-based segmentation (11 518 regions).

Let $S^{(0)}$ be the set of regions $r_{i}$ with a contrast to a neighbouring region $r_{j}$ greater than a given contrast threshold $c_{0}$ :

$S^{(0)}=\left\{r_{i} \in R: \exists r_{j} \in N\left(r_{i}\right): m\left(r_{j}\right) \geqslant c_{0}\right\}$,

where $m\left(r_{i}\right)$ is the mean grey value of region $r_{i}$ and $N\left(r_{i}\right)$ the set of neighbouring regions for region $r_{i}$. Every region $r_{i} \in S^{(0)}$ is pre-classified as a bacterial region. We use the regions in $S^{(0)}$ as start regions for a "region growing"-like (Ballard and Brown, 1982) process. Iteratively, neighbouring regions of regions classified as bacteria with a greater mean grey value are also pre-classified as bacterial regions. So the set of regions pre-classified as bacterial regions in the $(n+1)$ th iteration $(n \geqslant 1)$ is given by:

$S^{(n+1)}=S^{(n)} \cup\left\{r_{i}: r_{j} \in S^{(n)} \wedge r_{i} \in N\left(r_{j}\right) \wedge m\left(r_{i}\right) \geqslant m\left(r_{j}\right)\right\}$.

The termination condition is met if $S^{(n+1)}=S^{(n)}$.

Let now $S^{\left(n_{0}\right)}$ be the final state of the process described above. Then the initial label probabilities $P\left(r_{i}, l_{k}\right)$ for label $l_{k}$ assigned to region $r_{i}$, the compatibility coefficient $C\left(\left(r_{i}, l_{i}\right),\left(r_{j}, l_{j}\right)\right)$ that measures the compatibility of label $l_{i}$ assigned to region $r_{i}$ given that label $l_{j}$ is assigned to region $r_{j}$, and the impact parameter $W\left(r_{i}, r_{j}\right)$ measuring the impact of region $r_{j}$ on region $r_{i}$ for the relaxation labelling process (Kittler and Illingworth, 1986) are given as displayed in Fig. 8.

Iteratively the update rule

$P^{(n+1)}\left(r_{i}, l_{k}\right)=\frac{P^{(n)}\left(r_{i}, l_{k}\right)\left(1+\Delta P^{(n)}\left(r_{i}, l_{k}\right)\right)}{\sum_{l \in L} P^{(n)}\left(r_{i}, l\right)\left(1+\Delta P^{(n)}\left(r_{i}, l\right)\right)}$

is applied, where

$$
\begin{aligned}
\Delta P^{(n)}\left(r_{i}, l_{k}\right)= & \sum_{r_{j} \in R} W\left(r_{i}, r_{j}\right) \\
& \times\left[\sum_{l \in L} C\left(\left(r_{i}, l_{k}\right),\left(r_{j}, l\right)\right) P^{(n)}\left(r_{j}, l\right)\right]
\end{aligned}
$$

is the change in confidence for $P^{(n)}\left(r_{i}, l_{k}\right)$ in the $(n+1)$ th iteration. The termination condition is met if

$\forall r \in R, l \in L:\left|P^{(k)}(r, l)-P^{(k-1)}\right|<t_{0}$

for a given threshold $t_{0}$.

Finally, connected bacterial regions are extracted and further classified into patches and spots. Regions with a diameter greater than $40 \mathrm{~cm}$ are classified as patches, other regions are classified as spots (according to the classification scheme introduced in Jerosch et al., accepted). Fig. 9 shows the binary result of the region labelling and result of the classification into patches and spots. Fig. 10 


\section{Initial probabilities:}

$$
P^{(0)}(r, l)= \begin{cases}0.75 & :\left(l=l_{0} \wedge r \notin S^{\left(n_{0}\right)}\right) \vee\left(l=l_{1} \wedge r \in S^{\left(n_{0}\right)}\right) \\ 0.25 & : \text { otherwise }\end{cases}
$$

\section{Compatibility coefficient:}

$$
C\left(\left(r_{i}, l_{i}\right),\left(r_{j}, l_{j}\right)\right)= \begin{cases}1.0 & : l_{i}=l_{0} \wedge l_{j}=l_{0} \wedge m\left(r_{i}\right) \leq m\left(r_{j}\right) \\ 1-\delta & : l_{i}=l_{0} \wedge l_{j}=l_{0} \wedge m\left(r_{i}\right)>m\left(r_{j}\right) \\ 1.0 & : l_{i}=l_{0} \wedge l_{j}=l_{1} \wedge m\left(r_{i}\right)+c_{1} \leq m\left(r_{j}\right) \\ \delta & : l_{i}=l_{0} \wedge l_{j}=l_{1} \wedge m\left(r_{i}\right)+c_{1}>m\left(r_{j}\right) \\ 1.0 & : l_{i}=l_{1} \wedge l_{j}=l_{0} \wedge m\left(r_{i}\right) \geq m\left(r_{j}\right)+c_{1} \\ \delta & : l_{i}=l_{1} \wedge l_{j}=l_{0} \wedge m\left(r_{i}\right)<m\left(r_{j}\right)+c_{1} \\ 1.0 & : l_{i}=l_{1} \wedge l_{j}=l_{1} \wedge m\left(r_{i}\right) \geq m\left(r_{j}\right) \\ 1-\delta & : l_{i}=l_{1} \wedge l_{j}=l_{1} \wedge m\left(r_{i}\right)<m\left(r_{j}\right)\end{cases}
$$

for $\delta=\frac{\min \left(\left|m\left(r_{i}\right)-m\left(r_{j}\right)\right|, c_{1}\right)}{c_{1}}, m\left(r_{i}\right)$ : mean grey value of region $r_{i}$ and a given contrast parameter $c_{1}$.

\section{Impact parameter:}

$$
W\left(r_{i}, r_{j}\right)=\frac{1}{\left|N\left(r_{i}\right)\right|}
$$

where $N\left(r_{i}\right)$ : set of neighbouring image regions for region $r_{i}$

Fig. 8. Parameters of the relaxation labelling process: initial probabilities $P^{(0)}$, compatibility coefficient $C$, and impact parameter $W$ applied in the relaxation labelling step (Kittler and Illingworth, 1986).

additionally shows segmentation results for other images of the data set.

\subsection{Result export to GIS}

The analysis results are exported to GIS treatment-wise, where a treatment again is a row of consecutive mosaics, so the positioning is accurate enough to consider overlaps of the mosaic data regions. In the export the area covered by the data regions of the images of a treatment is further divided into small segments to gain precise local information about the spatial distribution of the detected bacterial coverage. Therefore, the union of the mosaic data regions is cut into segments of adjustable length (the default is $2 \mathrm{~m}$ ) along its major axis. Fig. 11 displays the resulting segments for the images of a single treatment.

The export of the detected bacterial coverage is then based on the atomic segments extracted as described in Section 3.2. As the union of atomic segments covers the complete treatment data and vice versa, every export segment is completely covered by such segments. For every export segment $e$ the set of intersecting atomic segments $A(e)$ is determined. Let now inter $(e, a)$ be the intersection of an export segment $e$ and an atomic segment $a, I(a)$ the set of images associated with an atomic segment $a$, and $\operatorname{cov}(i, r)$ the degree of bacterial coverage of a region $r$ in image $i$. Then the bacterial coverage $\operatorname{cov}(e)$ of export segment $e$, taking the average bacterial coverage for overlapping image segments, is computed as follows:

$$
\begin{aligned}
\operatorname{coverage}(e)= & \sum_{a \in A(e)} \frac{\operatorname{area}(\operatorname{inter}(e, a))}{\operatorname{area}(e)} \\
& \times\left[\frac{1}{\# I(a)} \sum_{i \in I(a)} \operatorname{cov}(i, \operatorname{inter}(e, a))\right] .
\end{aligned}
$$

Fig. 12 shows the exported results of the automatic analysis for the complete data set (all 4200 video mosaics). Currently, analysis results are exported to GIS via ESRI shapefiles (ESRI, 1998) - the de facto 

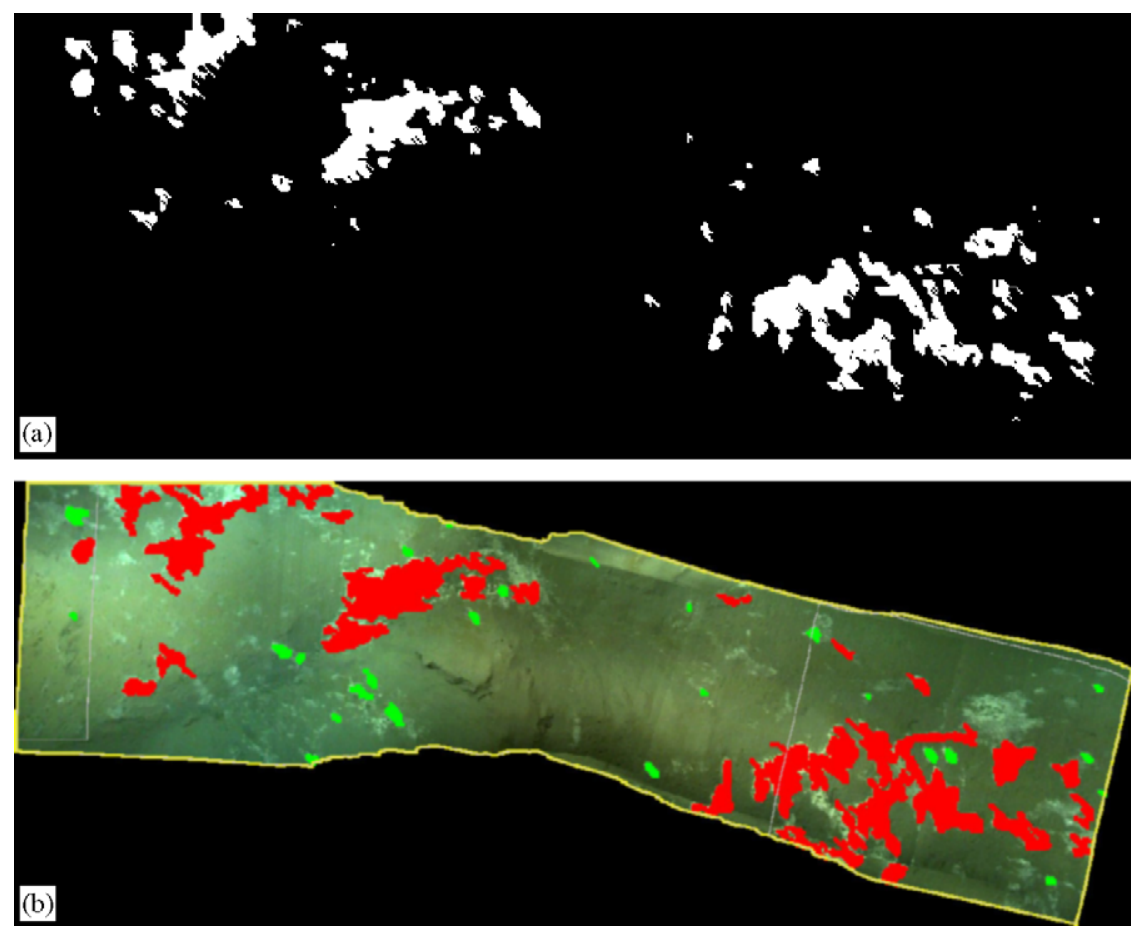

Fig. 9. (a) Binary result of region labelling. (b) Classification of bacterial regions into patches (connected segments with a diameter $\geqslant 40 \mathrm{~cm}$, red) and spots (green) according to the classification scheme used by Jerosch et al., accepted. The different categories indicate a spatial-temporal development stage of Beggiatoa.

standard for geospatial data exchange used by various GIS systems. Further integration into the ESRI GIS is planned for the future.

\section{Experimental results and comparison with visually inspected field data}

This section contains an evaluation of the proposed algorithm including extensive tests accomplished in a gradual procedure. Tests are based on a set of 4200 georeferenced video mosaics obtained during expedition ARK XIX3b of $R V$ Polarstern in 2003 providing information about the distribution and coverage degree of chemoautotrophic bacteria on the seafloor at the HMMV. Part of this data set (2840 video mosaics) was analysed manually by visual inspection, assigning four classes of coverage degree to subregions of each video mosaic:

(1) no Beggiatoa coverage,

(2) $>20 \%$ Beggiatoa coverage,

(3) $20-50 \%$ Beggiatoa coverage,

(4) $>50 \%$ Beggiatoa coverage.

A subset (related to the 2840 visually inspected mosaics) of 2310 video mosaics served as a working data set and was used during development and in experiments for adjustment of parameters like threshold values applied by the programmed algorithm. The other 530 visually examined mosaics served as a validation data set for tests of the algorithm applying the optimised parameterisation. The quality and performance of the image analysis was measured in terms of precision and recall, where precision measures the rate of correct detections of Beggiatoa according to the detections overall and recall measures the rate of correct detections according to the overall coverage (e.g. $20-50 \%$ coverage) estimated by visual inspection (Cleverdon et al., 1966). Since for the visually examined mosaics coverage classes were applied (see above), whereas single values were computed for each subregion covered by Beggiatoa, we assume a correct result of the automatic analysis if the result lies in the accordant interval. Otherwise we assume the measurable error, e.g. an error of $5 \%$ if a region is manually classified with $20-50 \%$ and the result of the automatic analysis predicts $55 \%$ of coverage. In the evaluation against the visually examined data set the algorithm performed as follows: 

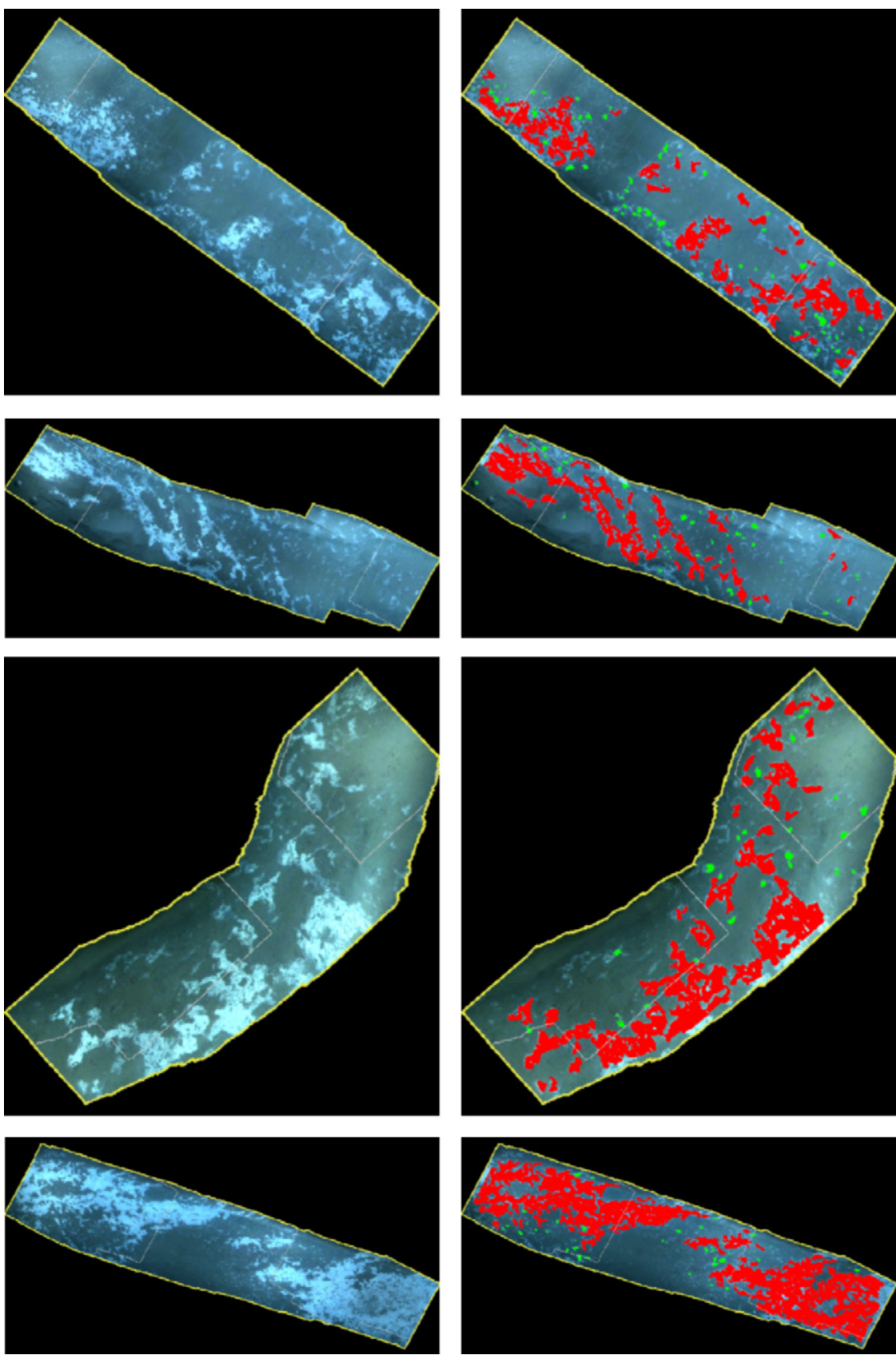

Fig. 10. Example segmentation results for images with Beggiatoa coverage of the data set. Images on the left column are the input data sets for the analysis. The red marked areas on the right visualise the results of the sedimentation process.

\begin{tabular}{llll}
\hline & $\begin{array}{l}\text { Working } \\
\text { set }\end{array}$ & $\begin{array}{l}\text { Validation } \\
\text { set }\end{array}$ & $\begin{array}{l}\text { Complete } \\
\text { set }\end{array}$ \\
\hline $\begin{array}{l}\text { Precision } \\
(\%)\end{array}$ & 92 & 90.6 & 91.4 \\
Recall (\%) & 76.1 & 90.2 & 81.8 \\
\hline
\end{tabular}

The average absolute measurable error (see above) per annotated region of the manually analysed data set was $2.06 \%$. Further divided into the coverage classes obtained by visual inspection the average 


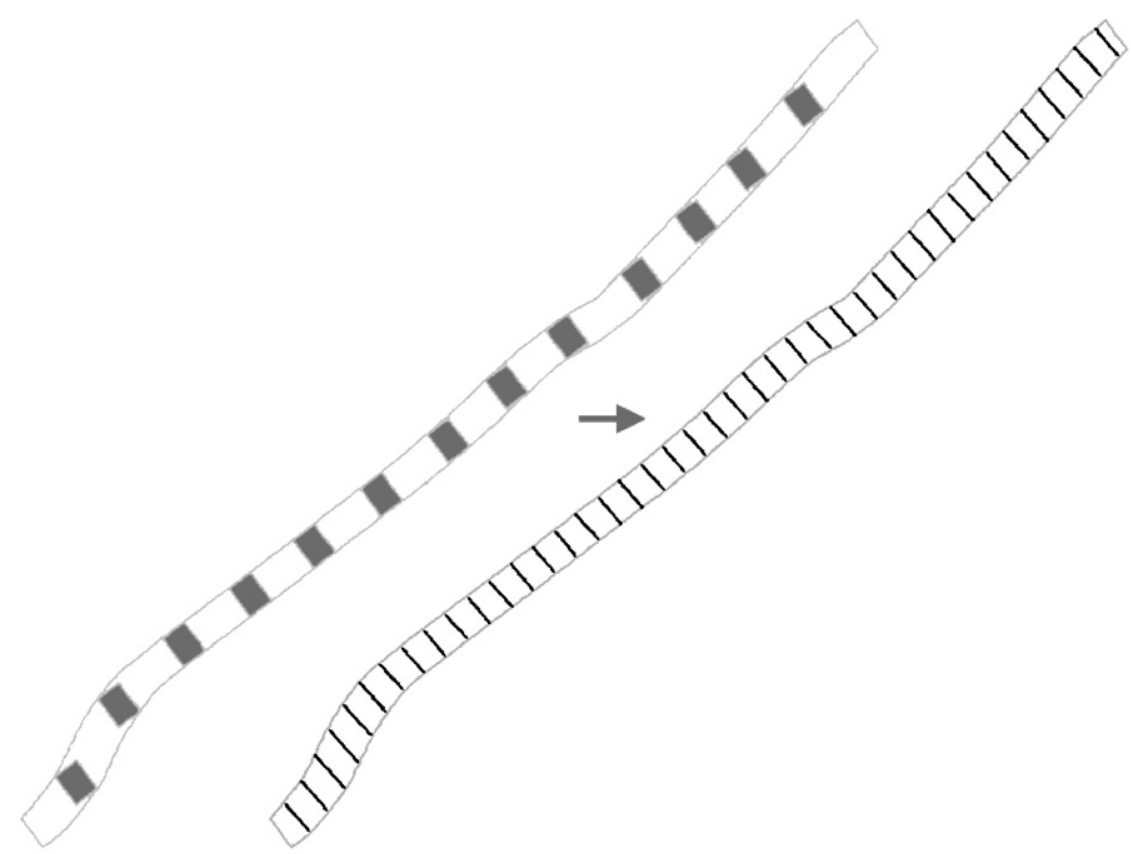

Fig. 11. Image data regions for a single treatment (overlaps marked dark) and resulting export segments.

absolute measurable error per class over the complete set was the following:

\begin{tabular}{lcl}
\hline Coverage class & \# regions & $\begin{array}{l}\oslash \text { Abs. } \\
\text { measurable } \\
\text { error }(\%)\end{array}$ \\
\hline $\begin{array}{l}\text { No Beggiatoa } \\
\text { coverage } \\
<20 \% \text { Beggiatoa } \\
\text { coverage }\end{array}$ & 1314 & 1 \\
$\begin{array}{l}20-50 \% \text { Beggiatoa } \\
\text { coverage } \\
>50 \% \text { Beggiatoa }\end{array}$ & 344 & 0.4 \\
$\begin{array}{l}\text { coverage } \\
\text { All classes }\end{array}$ & 122 & 8.8 \\
\hline
\end{tabular}

The regions annotated by the domain expert do not correspond to the mosaic data regions, so the numbers of regions and mosaics differ.

Fig. 13 shows a comparison of the results obtained by visual inspection and by automatic image analysis. As can be seen in the figure and from the recall of $\approx 80 \%$ the automatic detection of bacterial coverage tends to produce a slight underestimation of the bacterial coverage. This is mainly due to very slight bacterial coverage or insufficient illumination in certain image regions, where bacterial coverage has not been detected automatically but has been annotated by the domain expert during the visual analysis. Misdetections are mostly due to overexposure and reflections and light structures or objects similar to bacterial coverage on the seafloor. Examples for causes of undetected or misdetected bacterial coverage are displayed in Fig. 14.

The computation time for the analysis of the complete data set (all 4200 georeferenced video mosaics) was $\approx 4 \mathrm{~h}$ and $18 \mathrm{~min}$ on standard PC hardware. ${ }^{1}$ The computation time for the analysis of a single image varies, mainly because the run-time of the relaxation step increases when more bacteria is detected. The computation time for the analysis of a single image did not exceed $12 \mathrm{~s}$. The algorithm can therefore be regarded as real-time enabled for habitat mapping purposes as in our case with the MATISSE (Allais et al., 2004) system.

\section{Conclusions}

Coupled to the developments in the field of mobile underwater vehicles as ROVs and AUVs, digital image and video systems, and software combining video streams and navigation data into

\footnotetext{
${ }^{1}$ Athlon XP2600 + with 512 MB memory installed.
} 


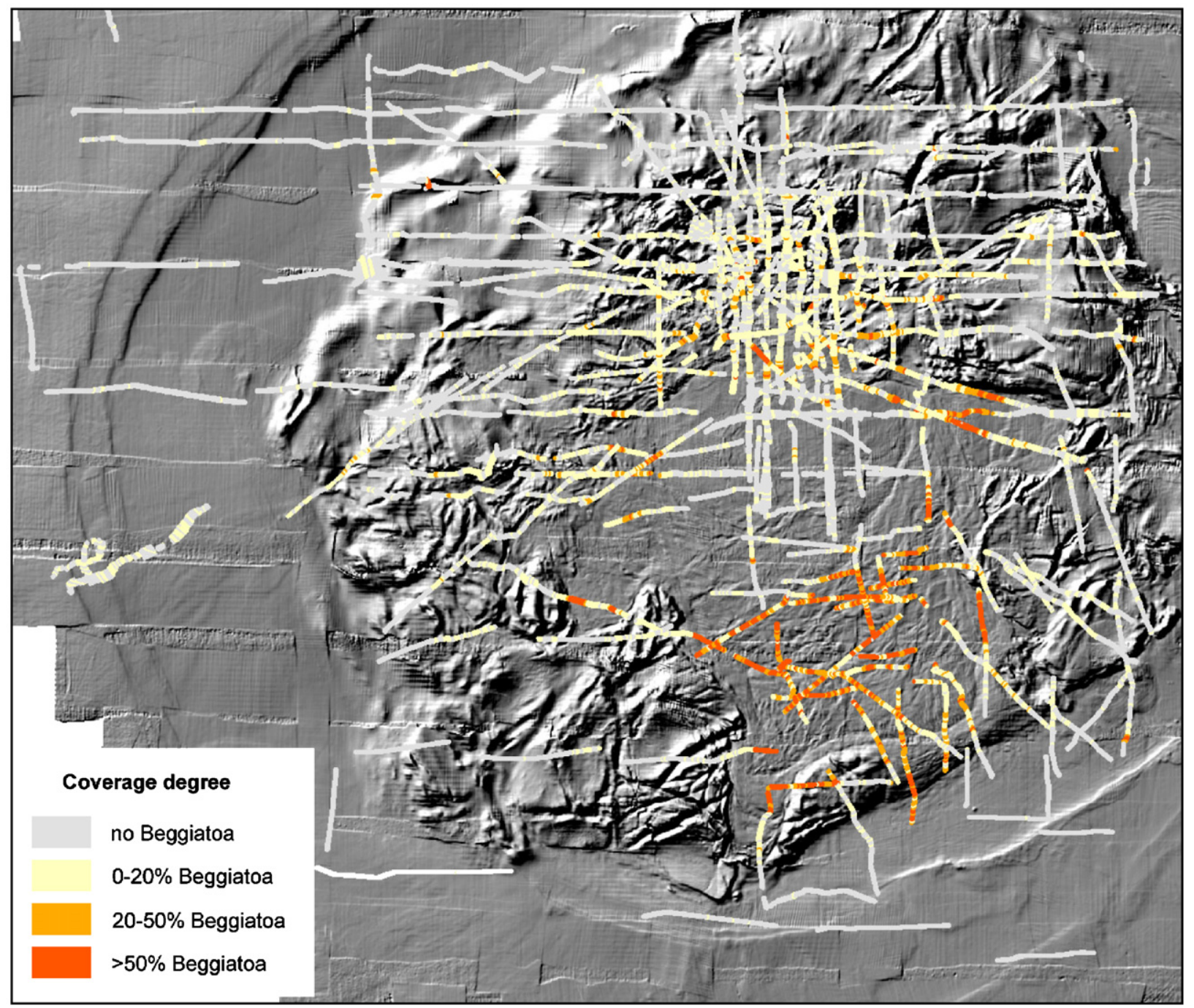

Fig. 12. Spatial distribution of bacterial coverage derived by the automated image analysis of 4200 video mosaics. The results were exported into the GIS and overlaid on the topography (visualised as hill shading map) of the HMMV.

georeferenced video mosaics is a fast increase of the number of studies and applications investigating spatial patterns at the seafloor or focused to identification of technical structures as pipelines.

To cope with the large number of video mosaics recorded during single dives of these vehicles semiautomated or even automated image analysis and feature detection are required. Related to investigations of the methane cycle at the HMMV an approach for a fully automatic detection and quantification of bacterial coverage at seafloor by analysis of video mosaics was developed. The proposed algorithm is based on techniques of digital image processing. A watershed transform (Roerdink and Meijster, 2000) is applied to partition video mosaics recorded during the ROV dives into sets of disjoint homogenous regions. These regions are then labelled as bacterial or non-bacterial using relaxation labelling (Kittler and Illingworth, 1986). The developed algorithm was tested against a visually examined data set of 2840 seafloor video mosaics and performed with comparable results. The evaluation data set was acquired using the ROV Victor6000 and the video mosaicing software MATISSE (Vincent et al., 2003). Automatic means of analysis like the proposed approach enable scientists rapidly to gain insight into newly acquired data without a time-consuming manual analysis by domain experts, however manual visual inspection cannot be totally replaced. This is particularly 
Coverage degree

\begin{tabular}{l|l} 
no Beggiatoa & $20-50 \%$ Beggiatoa \\
$0-20 \%$ Beggiatoa & $>50 \%$ Beggiatoa
\end{tabular}
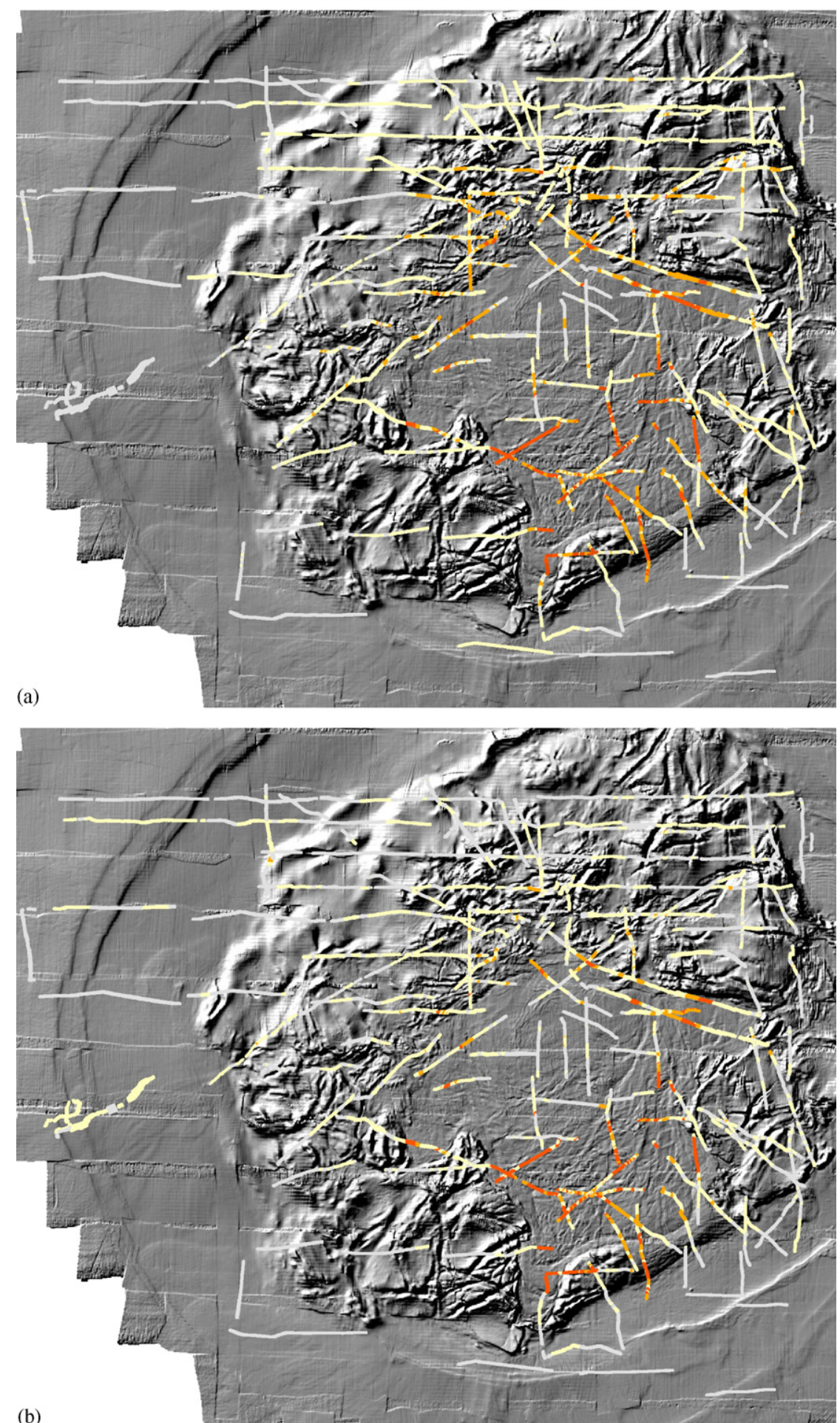

Fig. 13. (a) Coverage degree obtained by visual analysis of video mosaics. (b) Results obtained by automatic image analysis. The spatial coverage of Beggiatoa is overlain onto the bathymetry of HMMV visualised as hill shading map. 

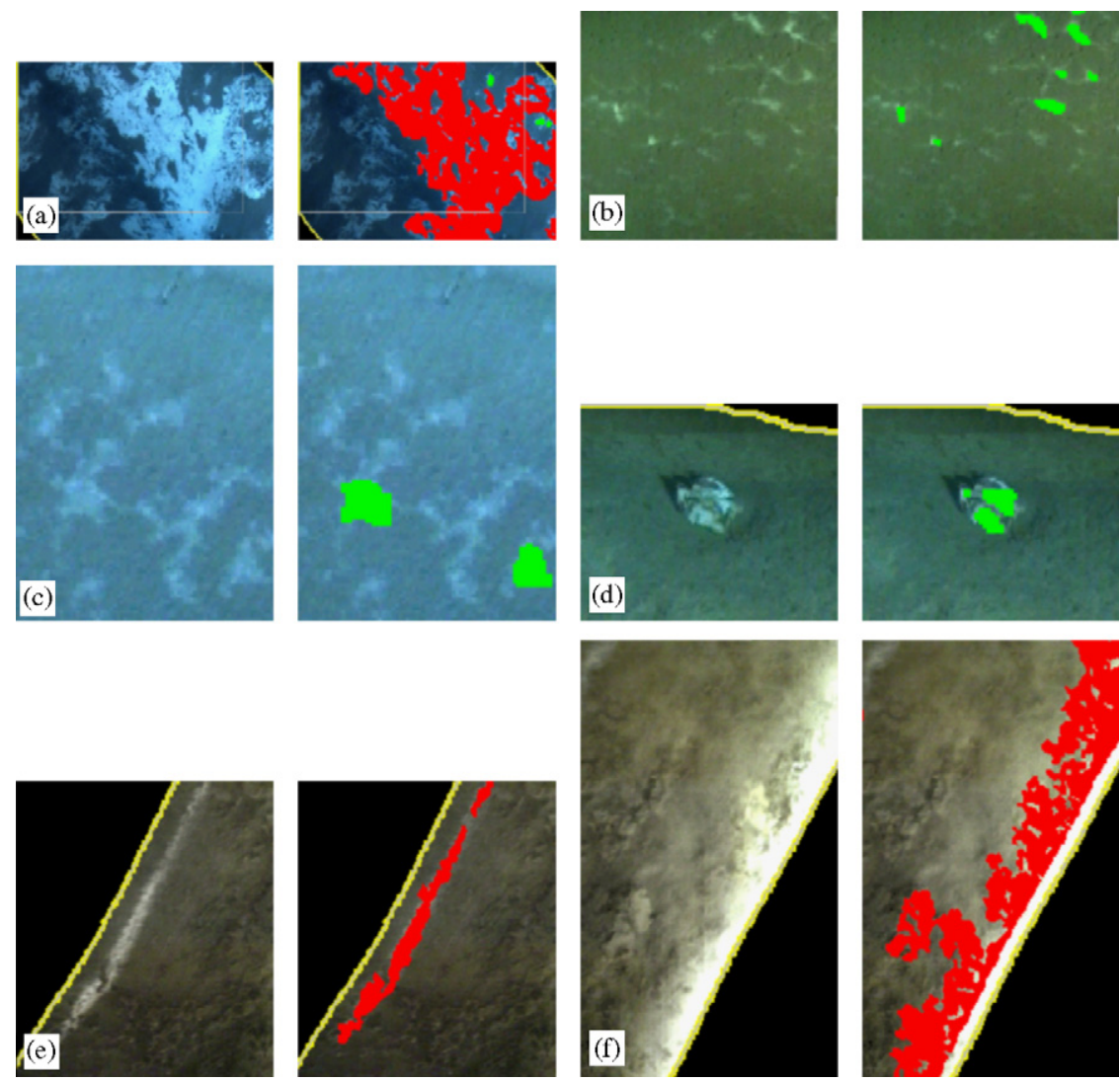

Fig. 14. (a) Undetected bacterial coverage due to insufficient illumination in the lower left. (b) and (c) Undetected shallow bacterial coverage. (d) Misdetection caused by object (presumably waste) on the seafloor. (e) and (f) Misdetections due to overexposure.

useful for the purposes of operations planning during an ongoing expedition. Furthermore, the availability of an automatic on-line analysis of image sensor data could enable unmanned fully autonomous devices to make decisions based on analysis results in the future, e.g. to further explore a site where interesting features (like bacterial seafloor coverage) have been detected. The GIS export of the analysis results allows further data processing. As investigations of geochemical processes - in our case the $\mathrm{CH}_{4}$ cycle-are often concerned with budgets, this is useful for subsequent data processing like interpolation and spatial area calculations.

\section{Acknowledgements}

The authors thank the IFREMER for the agreement for the use of the data which were produced in the framework of the AWI-IFREMER bilateral collaboration. We are grateful to V.
Rigaud and J. Opderbecke (IFREMER) for their support related to the MATISSE software and to the captain and the crew of $R V$ Polarstern and the Genavir team of ROV Victor6000 for their unremitting assistance. We highly appreciated the reviews and comments of A. Milkov and W. Sager. This is publication no. GEOTECH-203 of the programme GEOTECHNOLOGIEN of BMBF and DFG, Grant 03F0370A.

\section{References}

Allais, A.-G., Borgetto, M., Opderbecke, J., Pessel, N., Rigaud, V., 2004. In: Proceedings of 14th International Offshore and Polar Engineering Conference, vol. 2, Toulon, France, May 23-28, pp. 417-421.

Ballard, D.H., Brown, C.M., 1982. Computer Vision. PrenticeHall, Englewood Cliffs, NJ.

Beucher, S., 1991. In: Conference on Signal and Image Processing in Microscopy and Microanalysis, September, pp. 299-314.

Boetius, A., Ravenschlag, K., Schubert, C., Rickert, D., Widdel, F., Gieseke, A., Amann, R., Joergensen, B., Witte, U., 
Pfannkuche, O., 2000. A marine microbial consortium apparently mediating anaerobic oxidation of methane. Nature 407, 623-626.

Cleverdon, C.W., Mills, J., Keen, M., 1966. Factors determining the performance of indexing systems. College of Aeronautics, Cranfield (Beds.).

Crane, K., Vogt, P., Sundvor, E., Shor, A., Reed, T., 1995. In: Crane, K., Solheim, A. (Eds.), Seafloor Atlas of the Northern Norwegian-Greenland Sea, vol. 137. Norsk Polarinstitutt Meddelelser, Oslo, pp. 132-140.

Davies, E., 1990. Machine Vision: Theory, Algorithms and Practicalities. Academic Press, New York.

Edy, C., Bisquay, H., Foucher, J., Opderbecke, J., Simeoni, P., Allais, A., Beyer, A., Jerosch, K., Rathlau, R., 2004. General Assembly of the European Geosciences Union (EUG) Vienna, April 25-30.

Egorov, A., Crane, K., Vogt, P., Rozhkov, A., 1999. Gas hydrates that outcrop on the sea floor: stability models. GeoMarine Letters 19, 68-75.

ESRI, 1998. URL: 〈http://www.esri.com/〉.

Gebruk, A., Krylova, E., Lein, A., Vinogradov, G., Anderson, E., Pimenov, N., Cherkashev, G., Crane, K., 2003. Methane seep community of the Håkon Mosby mud volcano (the Norwegian Sea): composition and trophic aspects. Sarsia: North Atlantic Marine Science 88 (6).

Ginsburg, G., Milkov, A., Soloviev, V., Egorov, A., Cherkashev, G., Vogt, P., Crane, K., Lorenson, T., Khutorskoy, M., 1999. Gas hydrate accumulation at the Håkon Mosby Mud Volcano. Geo-Marine Letters 19, 57-67.

Hinrichs, K.U., Boetius, A., 2002. In: Wefer, G., Billett, D., Hebbeln, D., Joergensen, B., Schlüter, M., Weering, T.V. (Eds.), Ocean Margin Systems. Springer, Berlin, Heidelberg, pp. 457-477.

Hjelstuen, B., Eldholm, O., Faleide, J., Vogt, P., 1999. Regional setting of Håkon Mosby Mud Volcano, SW Barents Sea margin. Geo-Marine Letters 19 (1-2), 22-28.

Jerosch, K., Lüdtke, A., Schlüter, M., Ioannidis, G., 2005. General Assembly of the European Geosciences Union (EUG) Vienna, April 24-29.

Jerosch, K., Schlüter, M., Foucher, J.P., Allais, A.G., Klages, M., Edy, C., accepted. Spatial distribution of benthic communities affecting the methane concentration at Håkon Mosby Mud Volcano. Marine Geology.

Kaul, N., Heesemann, B., 2004. In: Klages, M., Thiede, J., Foucher, J.-P. (Eds.), The expedition ARK XIX/3 of the Research Vessel "Polarstern" in 2003. Berichte zur Polar-und Meeresforschung, 488, 346S.

Kittler, J., Illingworth, J., 1986. Relaxation labelling algorithms - a review. Image and Vision Computing 3 (4), 206-216.

Klages, M., Thiede, J., Foucher, J., 2004. Berichte zur Polar-und Meeresforschung, 488, 346S.

Kopf, A., 2002. Significance of mud volcanism. Reviews of Geophysics 40 (2).

Lein, A., Vogt, P., Crane, K., Egorov, A., Ivanov, M., 1999. Chemical and isotopic evidence for the nature of the fluid in
$\mathrm{CH}_{4}$-containing sediments of the Håkon Mosby Mud Volcano. Geo-Marine Letters 19, 76-83.

Milkov, A., 2000. Worldwide distribution of submarine mud volcanoes and associated gas hydrates. Marine Geology 167, $29-42$.

Milkov, A.V., Vogt, P.R., Cherkashev, G., 1999. Sea-floor terrains of Håkon Mosby Mud Volcano as surveyed by deep-tow video and still photography. Geo-Marine Letters $19,38-47$.

Milkov, A.V., Vogt, P.R., Crane, K., Lein, A.Y., Sassen, R., Cherkashev, G., 2004. Geological, geochemical, and microbial processes at the hydrate-bearing Håkon Mosby Mud Volcano: a review. Chemical Geology 205, 347-366.

Pimenov, N., Savvichev, A., Rusanov, I., Lein, A., Ivanov, M., 2000. Microbiological processes of the carbon and sulphur cycles at cold methane seeps of the North Atlantic. Microbiology 69, 709-720.

Roerdink, J.B.T.M., Meijster, A., 2000. The watershed transform: definitions, algorithms and parallelization strategies. Fundamenta Informaticae 41 (1-2), 187-228.

Sager, W., MacDonald, I., Hue, R., 2003. Geophysical signatures of mud mounds at hydrocarbon seeps on the Louisiana continental slope, northern Gulf of Mexico. Marine Geology 198, 97-132.

Sager, W., MacDonald, I., Hue, R., 2004. Side scan sonar imaging of hydrocarbon seeps on the Louisiana continental slope. American Association of Petroleum Geologists Bulletin 88, 725-746.

Sahling, H., Galkin, S.V., Salyuk, A., Greinert, J., Foerstel, H., Piepenburg, D., Suess, E., 2003. Depth-related structure and ecological significance of cold-seep communities - a case study from the Sea of Okhotsk. Deep-Sea Research I 50, 1391-1409.

Sahling, H., Wallmann, K., Dählmann, A., Schmaljohann, R., Petersen, S., 2005. The physicochemical habitat of Sclerolinum sp. at Hook Ridge hydrothermal vent, Bransfield Strait, Antarctica. Limnology and Oceanography 50 (2), 598-606.

Sauter, E.J., Muyakshin, S.I., Charlou, J.-L., Schlüter, M., Boetius, A., Jerosch, K., Damm, E., Foucher, J.-P., Klages, M., 2006. Methane discharge from a deep-sea submarine mud volcano into the upper water column by gas hydrate-coated methane bubbles. Earth and Planetary Science Letters 243 (3/4), 354-365.

Smirnov, R., 2000. Two new species of pogonophoran from the arctic mud volcano off northwestern Norway. Sarsia 85, 141-150.

Soltwedel, T., Portnova, D., Kolar, I., Mokievsky, V., Schewe, I., 2005. The small-sized benthic biota of the Håkon Mosby Mud Volcano (SW Barents Sea slope). Journal of Marine Systems 55, 271-290.

Vincent, A., Jouffroy, J., Pessel, N., Opderbecke, J., Borgetto, M., Rigaud, V., 2003. In: Proceedings of the Oceans 2003 Marine Technology and Ocean Science Conference, MTS/ IEEE OCEANS'03, vol. 4, San-Diego, USA, September 22-26, pp. 2319-2324. 